This PDF is a selection from an out-of-print volume from the National Bureau of Economic Research

Volume Title: International Taxation and Multinational Activity

Volume Author/Editor: James R. Hines, Jr.

Volume Publisher: University of Chicago Press

Volume ISBN: 0-226-34173-9

Volume URL: http://www.nber.org/books/hine00-1

Conference Date: November 14-15, 1997

Publication Date: January 2000

Chapter Title: The Impact of Transfer Pricing on Intrafirm Trade

Chapter Author: Kimberly A. Clausing

Chapter URL: http://www.nber.org/chapters/c10724

Chapter pages in book: (p. 173 - 200) 


\title{
The Impact of Transfer Pricing on Intrafirm Trade
}

\author{
Kimberly A. Clausing
}

\subsection{Introduction}

Multinational companies play a very large role in international trade. Not only is there a substantial amount of arm's-length trade between MNCs and unaffiliated buyers, but trade within MNCs is also quite considerable. For instance, in 1994, this intrafirm trade accounted for approximately 36 percent of U.S. exports and 43 percent of U.S. imports. These fractions vary somewhat from year to year, but intrafirm trade has been a similarly large share of international trade since $1977 .{ }^{1}$

Recently, researchers have devoted some attention to examining how intrafirm trade may be different from arm's-length trade. ${ }^{2}$ One essential reason intrafirm trade may differ from nonintrafirm trade results from the fact that MNCs may alter their transactions in order to minimize worldwide tax burdens. It has long been recognized, for example, that firms may employ transfer pricing techniques that allow them to shift profits to lowtax locations, thus lowering their overall tax burdens. The empirical evidence indicates that such motivations are not just a theoretical possibility.

Using data on the operations of U.S. parent companies and their foreign affiliates, this paper examines the extent to which tax-minimizing behavior

Kimberly A. Clausing is assistant professor of economics at Reed College.

The author is grateful to James Hines, Deen Kemsley, Joel Slemrod, and other conference participants for many helpful comments.

1. The earliest year for which comparable data are available is 1977. See Zeile (1997) for additional information regarding trends in intrafirm trade.

2. For example, Rangan and Lawrence (1999) examine the response of U.S. MNCs to exchange rate fluctuations. In addition, a large literature (Blomström, Lipsey, and Kulchycky 1988; Lipsey and Weiss 1981, 1984; Grubert and Mutti 1991; Clausing 2000; etc.) considers the relationship between trade and multinational activity. 
influences intrafirm trade patterns. The results indicate that taxes have a substantial influence on intrafirm trade flows. First, controlling for other factors that are likely to influence intrafirm trade balances, the data indicate that the United States has less favorable intrafirm trade balances with low-tax countries. This result is anticipated if U.S. sales to affiliates in lowtax countries are underpriced and U.S. purchases from affiliates in low-tax countries are overpriced. Second, additional evidence indicates that trade between U.S. affiliates in different foreign countries is also likely influenced by tax considerations. Sales by affiliates based in low-tax countries are greater than one would otherwise expect relative to sales by affiliates based in high-tax countries.

These results have several interesting implications. First, they indicate an important way in which intrafirm trade flows may indeed be different from international trade conducted at arm's length. Intrafirm trade flows are influenced by the tax minimization strategies of MNCs. Second, the results add evidence that transfer prices are influenced by tax considerations. Much of the previous literature has considered this question by focusing on firm profitabilities or tax liabilities; this paper shows how the actual transactions between countries are affected by transfer pricing strategies.

Section 7.2 will discuss the relationship between the tax minimization strategies of MNCs and intrafirm trade. It will review the previous theoretical and empirical literature in this area, and generate a simple model that demonstrates the relationship between taxes and intrafirm trade. Section 7.3 will consider the data on intrafirm trade between U.S. parents and their affiliates abroad, examining specifications that relate such intrafirm trade to the tax rates faced by affiliates in different countries. Section 7.4 considers the data on intrafirm trade between different foreign affiliates of U.S. firms, examining both the impact of transfer pricing on intrafirm trade and the potential impact of the subpart F provisions of U.S. tax law on intrafirm trade. Section 7.5 concludes.

\subsection{The Impact of Tax Minimization Strategies on Intrafirm Trade}

Multinational firms can typically lower their overall tax burdens by shifting profits toward low-tax countries and away from high-tax countries. Horst (1971) generated a simple model that shows how MNCs choose transfer prices in order to maximize their after-tax earnings. The model analyzes the choices of a monopolistic firm selling in two countries simultaneously. The firm's earnings are equal to its after-tax profits in the two countries plus a term that shows the impact of intrafirm trade. This generates a situation in which a firm chooses either the lowest or highest transfer price possible, depending on a comparison of the relative differential in tax rates between the importing and exporting countries with the tariff rate. 
Eden (1985) and Diewert (1985) have demonstrated that such transfer pricing can affect intrafirm trade. Kant $(1990,1995)$ has elaborated on these insights, considering the likely impact of transfer pricing on intrafirm trade and government revenues. The 1990 model incorporates transfer pricing penalties and partial ownership. Transfer pricing penalties imply that there is a trade-off between the optimal transfer price and the probability of a penalty, leading to a solution in which the price is set closer to the arm's-length price than would be optimal from a profit perspective. Partial ownership implies that firms may be encouraged to shift profits home, ceteris paribus, because firms may own only a part of affiliates. Kant (1995) broadens the model to consider the impact of deferral of nonrepatriated foreign profits on intrafirm trade, and finds that both deferral and partial ownership can lead to situations in which intrafirm trade is perverse, such that intrafirm exports originate in the country with the higher marginal cost.

Many empirical studies (such as Lall 1973; Jenkins and Wright 1975; Kopits 1976; Bernard and Weiner 1990; Grubert and Mutti 1991; Harris, Morck, Slemrod, and Yeung 1993; Hines and Rice 1994; and Collins, Kemsley, and Lang 1996) have estimated the magnitude of tax-induced transfer pricing. Due to data limitations, the evidence is necessarily indirect, but most studies indicate that transfer prices are likely to be influenced by tax considerations. Many studies focus on the profitability of affiliates in different countries. Jenkins and Wright (1975) examine the profitability of U.S. oil companies, finding that affiliates in low-tax rate countries are more profitable. Grubert and Mutti (1991) find that high taxes reduce after-tax profitabilities of local operations. Hines and Rice (1994) find even larger effects, suggesting that 1 percent tax rate differences are associated with 2.3 percent differences in before-tax profitability.

Collins, Kemsley, and Lang (1996) study the relationship between profit margins of U.S. MNCs and foreign tax rates, finding evidence of taxmotivated income shifting, particularly income shifting into the United States from high-tax countries. Harris et al. (1993) consider U.S. tax liabilities, finding that U.S. MNCs with tax haven affiliates have significantly lower tax liabilities than would otherwise be expected. Finally, Kemsley (1997) finds a positive relationship between a firm's propensity to serve (unaffiliated) customers by exporting (relative to foreign production) and the foreign tax rate, due to special export tax rules (IRC $\$ 863[\mathrm{~b}]$ ) that raise the tax incentive favoring exports.

If U.S. MNCs manipulate transfer prices in order to minimize worldwide tax burdens, then one may expect a country's tax rate to have an influence on the magnitudes of intrafirm trade flows between the United States and that country. For example, one method for shifting profits between countries is to underprice goods sold to affiliates in low-tax countries and overprice goods sold by affiliates in low-tax countries, following 
the opposite pattern for transactions with affiliates in high-tax countries. Such a strategy would suggest that intrafirm trade flows to (from) low-tax country affiliates should be low (high) relative to intrafirm trade flows to (from) high-tax country affiliates, ceteris paribus. On net, these tax considerations imply that U.S. intrafirm trade balances should be more favorable with high-tax countries than with low-tax countries.

Following Horst (1971) and Kant (1995), one can produce a simple model that generates this prediction. Consider an MNC with some degree of market power that is operating in two countries. It produces and sells in each country, and also exports part of its output from the home country (1) to the affiliate abroad (2). ${ }^{3}$ For now, assume that the affiliate is fully owned. ${ }^{4}$

Profit functions for operations in the two countries are given by the following equations:

$$
\begin{aligned}
& \pi_{1}=R_{1}\left(s_{1}\right)-C_{1}\left(s_{1}+m\right)+p m, \\
& \pi_{2}=R_{2}\left(s_{2}\right)-C_{2}\left(s_{2}-m\right)-p m,
\end{aligned}
$$

where $\pi_{1}$ is profit in the home country, which depends on revenues $R_{1}$ that are a function of sales $\left(s_{1}\right)$ and costs $\left(C_{1}\right)$ that are a function of production. Production includes both those goods sold at home and those sent to the affiliate abroad $(m)$. The output that is exported to the affiliates abroad is given the transfer price $p$.

Consider the case in which tax rates at home are greater than tax rates abroad $\left(t_{1}>t_{2}\right)$ and deferral is allowed. Let $f$ represent the fraction of profits that are repatriated. The effective tax rate $\left(t^{e}\right)$ on income earned in the affiliate country is then

$$
t_{2}^{e}=t_{2}+\left(t_{1}-t_{2}\right) f .
$$

The net profit function for the firm's global operations is

$$
\pi=\left(1-t_{1}\right) \pi_{1}+\left(1-t_{2}^{e}\right) \pi_{2} .
$$

To illustrate how the firm may choose a transfer price in order to maximize these net profits, consider the derivative of equation (4) with respect to the transfer price $p$.

$$
\pi_{p}=\left(1-t_{1}\right) m-\left(1-t_{2}^{e}\right) m
$$

3. It is straightforward to extend this model to consider trade that originates in the affiliate country. One can also consider this trade to be in intermediate products without affecting the basic insights developed here.

4. The implications of relaxing this assumption are considered in Kant (1995) and briefly discussed later. 
Substituting for $t_{2}^{e}$ using equation (3) and rearranging,

$$
\pi_{p}=-\left(t_{1}-t_{2}\right)(1-f) m .
$$

So, if $t_{1}>t_{2}$, the previous expression is negative, and the firm's net profits decrease with the transfer price. Thus, firms have an incentive to underprice goods sold to low-tax countries in order to shift profits to low-tax locations. Similarly, one can show that firms have an incentive to overprice goods sold to high-tax affiliates when $t_{2}>t_{1} \cdot{ }^{5}$

This analysis implies that firms will want to charge the lowest transfer price possible when $t_{1}>t_{2}$. As Kant (1990) reminds us, however, two considerations may interfere with this motivation. First of all, a firm may be subject to penalties if its manipulation of transfer prices is too flagrant. If the probability of receiving a penalty increases as the transfer price is further from the arm's-length price, the firm will likely choose a transfer price that balances the gain from profit shifting with the possibility of a penalty. ${ }^{6}$ Second, affiliates may not be wholly owned. This creates a second profit-shifting incentive, as a firm may choose to overprice shipments to affiliates to transfer profits to sources that are wholly owned and away from partially owned sources. ${ }^{7}$

The tax minimization incentives demonstrated previously generate similar predictions regarding intrafirm trade among different foreign affiliates of U.S. firms. One would expect, ceteris paribus, affiliates from low-tax countries to have higher sales to other foreign affiliates than do affiliates from high-tax countries. However, the incentives here are slightly more complicated. Under the subpart F provisions of U.S. tax law, U.S. firms are not eligible to defer taxation on unrepatriated foreign income that is derived from sales of goods between related parties where the goods are both manufactured outside the base country and sold for use outside the base country. ${ }^{8}$ Basically, this provision implies that trade between foreign affiliates will be discouraged if such trade generates subpart $\mathrm{F}$ income and if affiliates find deferral a clear advantage. Affiliates that are located in low-tax countries are more likely to find deferral advantageous, ceteris paribus. Thus, subpart $\mathrm{F}$ acts as a second effect on trade between different foreign affiliates of U.S. firms that may act to offset the profit-shifting incentives discussed previously.

5. Note that these models implicitly assume that there is only one transfer price $p$; that is, firms keep just one set of books. Firms in reality may keep more than one set of books, using one set of prices to minimize tax liabilities and other sets of prices for other purposes, such as determining the relative performance of affiliates.

6. This consideration alters the degree of transfer price manipulation, but would not alter the desired direction of underpricing or overpricing.

7. While this consideration may influence the desired direction of transfer price changes, it also assumes that firms are free to manipulate transfer prices without the need to be responsive to the profits of their minority interests.

8. See Rapakko (1990) for a detailed description of these provisions. 


\subsection{Intrafirm Trade between U.S. Parents and Affiliates}

Using data on intrafirm trade flows from the Bureau of Economic Analysis (BEA) surveys of U.S. direct investment abroad, this paper attempts to clarify the impact of tax-minimizing behavior on intrafirm trade flows. The analysis employs country-level data, because tax rates vary primarily by country (rather than by industry). It is possible to consider these relationships both across countries and over time because BEA surveys are available on an annual basis between 1982 and 1994. In this section, the analysis will focus on intrafirm trade flows between U.S. parents and their affiliates abroad, as illustrated in figure 7.1. In the following section, the analysis will turn to intrafirm trade between different foreign affiliates of U.S. firms.

The basic specification explains intrafirm trade flows as a function of tax rates and other exogenous variables that are likely to affect trade flows.

$$
\begin{aligned}
\text { Intrafirm Trade Balance }_{i t}= & \alpha+\beta_{1} \text { Effective Tax Rate }_{i t} \\
& +\beta_{2} \text { Real Exchange Rate }_{i t} \\
& +\beta_{3} \text { Income Growth }_{i t}+\beta_{4} \text { ShareWh }_{i t} \\
& +\beta_{5} \text { ShareM }_{i t}+\beta_{6} \text { Trade Balance }_{i t} \\
& +\beta_{7} \text { Unaffiliated Trade Balance }_{i t}+e_{i t}
\end{aligned}
$$

Section III: Intrafirm Trade Flows between U.S. Parents and Their Affiliates

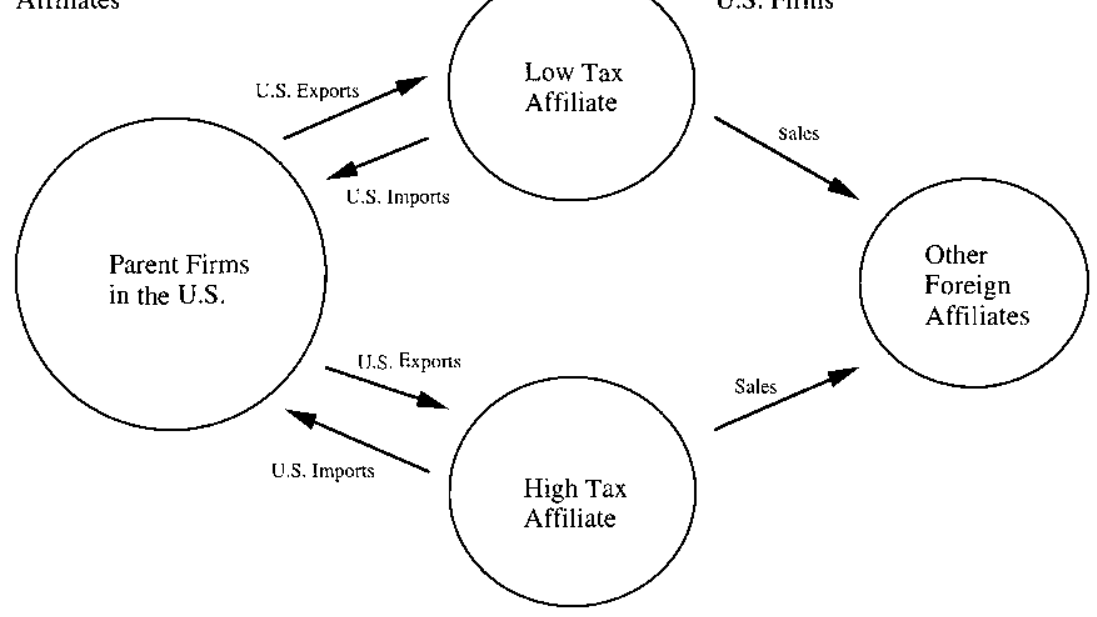

Fig. 7.1 Two approaches to analyzing the relationship between transfer pricing and intrafirm trade 


\begin{tabular}{lccc}
\hline Variable & $N$ & Mean & $\begin{array}{c}\text { Standard } \\
\text { Deviation }\end{array}$ \\
\hline Intrafirm trade balance & 524 & .2627 & .4843 \\
Effective tax rate & 651 & .3450 & .2231 \\
Real exchange rate & 612 & 133.1 & 47.75 \\
Income growth & 605 & 3.395 & 4.091 \\
Share of sales in wholesale trade & 583 & .1976 & .1479 \\
Share of sales in manufacturing & 629 & .3841 & .2481 \\
Overall trade balance & 635 & -.0649 & .3200 \\
$\quad$ Unaffiliated trade balance & 561 & .2932 & .5291 \\
Sales to affiliates in other foreign & & & \\
$\quad$ countries & 589 & 2,530 & 5,149 \\
Sales to nonaffiliates in other & & & \\
$\quad$ foreign countries & 595 & 2,292 & 4,317 \\
$\quad$ Total sales & 651 & 19,171 & 35,543 \\
\hline
\end{tabular}

Note: The data cover the period 1982-94. Fifty-eight countries are included. Each observation represents one country $(i)$ and one year $(t)$. "Intrafirm trade balance" is the amount of U.S. exports sent from parent firms to U.S. affiliates in country $i$ minus the amount of U.S. imports sent from U.S. affiliates in country $i$ to U.S. parents, relative to the total amount of trade between U.S. parents and their affiliates in country $i$. "Effective tax rate" is foreign income taxes paid relative to income. "Real exchange rate" is an index where $1980=100$, calculated using nominal exchange rates and price indexes in the United States and country $i$. "Income growth" is the growth in real GDP for country $i$ in year $t$. "Share of sales in wholesale trade/manufacturing" are shares of total sales that are in wholesale trade/manufacturing. "Overall trade balance" is total U.S. exports to country $i$ minus total U.S. imports from country $i$, relative to total trade between the United States and country $i$ (excluding intrafirm trade between parents and affiliates in country $i$ ). "Unaffiliated trade balance" is U.S. exports by unaffiliated persons to affiliates in country $i$ minus U.S. imports sent from U.S. affiliates in country $i$ to unaffiliated persons in the United States, relative to the total trade between unaffiliated persons in the United States and affiliates in country $i$. "Sales to affiliates in other foreign countries" are sales by affiliates in country $i$ to affiliates in other foreign countries. "Sales to nonaffiliates in other foreign countries" are sales by affiliates in country $i$ to unaffiliated persons in other foreign countries. "Total sales" are the total sales in all locations by affiliates in country $i$. Real exchange rate and income growth data come from the International Monetary Fund's International Financial Statistics yearbooks. Overall trade data come from the U.S. International Trade Commission. All other data come from the Bureau of Economic Analysis annual surveys of U.S. Direct Investment Abroad.

Table 7.1 defines and summarizes the variables used in the analysis. The dependent variable is the intrafirm trade balance between the United States and the country hosting U.S. affiliates. The intrafirm trade balance is the amount of U.S. exports sent from parent firms to their affiliates abroad minus the amount of U.S. imports sent from affiliates to U.S. parents, relative to the total amount of trade between the U.S. parents and affiliates.

The tax rate variable used is an effective tax rate (ETR): foreign income taxes paid relative to income. Although using marginal tax rates is a theoretically superior alternative, the published marginal tax rates are an im- 
perfect proxy for the actual tax rates firms face, because such rates do not account for the many subtleties (tax holidays, ad hoc arrangements, etc.) that determine the true tax treatment of firms. ${ }^{9}$

This basic specification offers a starting point for examining the influence of taxes on trade patterns between the United States and host countries. If host-country taxes are low, and firms systematically employ transfer pricing to shift profits to low-tax countries, one would expect U.S. intrafirm trade balances to be less favorable with such countries because intrafirm exports from the United States are underpriced and intrafirm imports into the United States are overpriced. Thus, if taxes affect trade patterns in the manner previously hypothesized, the expected sign of $\beta_{1}$ is positive.

The specification also includes other variables that are likely to affect intrafirm trade flows. These variables fall into three categories. First of all, I include two variables that reflect bilateral economic conditions: (1) the strength of the dollar relative to the affiliate country currency, measured by the real exchange rate between the two countries, and (2) the income growth of the affiliate country - one expects the United States to have more favorable trade balances when income growth abroad is relatively strong. ${ }^{10}$

In the second category, I include variables that reflect the character of affiliate operations in the host country. Countries where affiliate activities are primarily concentrated in wholesale trade may have substantially different trade patterns with the United States than do countries where affiliate activities are concentrated in manufacturing, finance, petroleum, or service industries. Share $\mathrm{Wh}_{i t}$ is the share of affiliate sales in country $i$ (and year $t$ ) that are in the wholesale trade industry; Share $\mathbf{M}_{i t}$ is the share of affiliate sales that are in manufacturing industries. Dummy variables are also included in some specifications for countries that may have unique intrafirm trade relationships. ${ }^{11}$

In the third category I include other types of trade balances between the United States and the country in question. I include the total (excluding intrafirm trade) trade balance between the two countries, as a possible control for other factors that may influence the pattern of trade between the two countries. I also include the trade balance between affiliates abroad and nonaffiliated persons in the United States, as a possible control for characteristics of affiliates that may influence their trade with the United States.

Results are shown in table 7.2. The basic specification just described is

9. In addition, the average tax rates for this sample (of fifty-eight countries and thirteen years) are more readily available.

10. Most empirical studies of trade flows have utilized such variables because there are strong theoretical rationales for including them; see Deardorff (1998).

11. I include dummies for Japan and for the European countries as a group in some specifications. 
Table 7.2

Dependent Variable: Intrafirm Trade Balance

\begin{tabular}{lccc}
\hline Independent & & & \\
Variables & $(1)$ & $(2)$ & $(3)$ \\
\hline Effective tax rate & .4353 & .5179 & .4226 \\
& $(.0956)$ & $(.0967)$ & $(.1090)$ \\
Real exchange rate & .0013 & .0009 & .0011 \\
& $(.0004)$ & $(.0004)$ & $(.0004)$ \\
Income growth & -.0058 & -.0090 & -.0095 \\
& $(.0046)$ & $(.0047)$ & $(.0050)$ \\
Share of sales in wholesale trade & 1.179 & 1.506 & 1.236 \\
& $(0.154)$ & $(.141)$ & $(0.167)$ \\
Share of sales in manufacturing & .1913 & .2496 & .2892 \\
& $(.0830)$ & $(.0832)$ & $(.0873)$ \\
Overall trade balance & .8607 & .8367 & .8999 \\
& $(.0644)$ & $(.0649)$ & $(.0685)$ \\
Unaffiliated trade balance & .0231 & .0566 & -.0201 \\
& $(.0346)$ & $(.0349)$ & $(.0363)$ \\
European country dummy & .1660 & & .1445 \\
& $(.0400)$ & & $(.0416)$ \\
Japan dummy & .4292 & .4385 \\
& $(.1071)$ & & $(.1060)$ \\
Constant & -.3580 & -.3548 & -.3392 \\
& $(.0884)$ & $(.0909)$ & $(.0965)$ \\
$N$ & 449 & 449 & 397 \\
Adjusted $R^{2}$ & .425 & .392 & .447 \\
\hline
\end{tabular}

Note: Standard errors are in parentheses. Columns (1) and (2) include all country/year pairs for which data are available. Column (3) excludes those countries defined as tax havens, where the effective tax rate is less than 10 percent. For variable definitions refer to table 7.1 note.

column (1). The coefficient on the effective tax rate variable indicates that an effective tax rate in the affiliate country 10 percentage points higher is associated with an intrafirm trade balance relative to country $i$ that is 4.4 percentage points greater. The fitted values from these regression results imply that the United States would have an intrafirm trade balance of 0.26 with a country that had an effective tax rate at the mean (0.33). Holding the other variables constant, the results suggest that the intrafirm trade balance with a country with an effective tax rate in the 10th percentile would be 0.14 , whereas the intrafirm trade balance with a country with an effective tax rate in the 90th percentile would be 0.39 .

Most of the other coefficients in the regression were approximately as expected. The real exchange rate coefficient indicates that as the dollar is stronger, intrafirm trade balances improve. ${ }^{12}$ This contradicts one's expec-

12. When exchange rate lags were included, they were not statistically significant, nor did they improve the fit of the regression or noticeably change the other coefficients of interest. Therefore, they are not included for the results presented here. 
tation that the U.S. trade balances should be more favorable when the dollar is depreciated. On the other hand, if intrafirm trade quantities are relatively fixed or slow to change, than intrafirm trade balances may actually improve in dollar terms when the dollar is appreciated, due to J-curve-type effects. Income growth abroad does not have a statistically discernible impact on intrafirm trade balances.

Both the share of sales in wholesale trade and the share of sales in manufacturing are positively associated with intrafirm trade balances, with the share of sales in wholesale trade having a particularly large effect. For instance, if affiliates in country $i$ have a 10 percent higher share of their total sales in wholesale trade, one can expect the United States to have intrafirm trade balances with country $i$ that are 12 percentage points greater. The United States tends to have more favorable intrafirm trade balances with European countries and Japan. Column (2) shows the same specification as column (1), excluding these dummy variables. This specification indicates that the inclusion of these variables does not affect most other coefficients in a statistically discernible fashion.

There is a strong and statistically significant positive relationship between the U.S. overall trade balance (excluding intrafirm trade) with a country and the intrafirm trade balance. This is perhaps due to common country-specific factors that affect both types of trade balances, including the relative savings/investment balance in the two countries. ${ }^{13}$ The relationship between the intrafirm trade balance and the trade balance between affiliates in country $i$ and unaffiliated U.S. persons is not statistically significant.

Column (3) tests the basic specification, excluding countries that are defined as tax havens. For simplicity, I define tax havens to be those countries where the effective tax rate is less than 10 percent. ${ }^{14}$ The results from this specification indicate that the tax effects shown are not dependent solely on those countries in the sample with the lowest tax rates.

However, it is the case that the tax sensitivity of intrafirm trade is driven by those countries in the sample whose effective tax rates are less than the U.S. tax rate. In particular, if one divides the sample into two groups of observations based on whether the effective tax rate is lower or higher than the U.S. marginal tax rate, one finds that the relationship between taxes and intrafirm trade is much more dramatic for the low-tax group. Results are shown in table 7.3. ${ }^{15}$

13. Countries that save more than they invest run global trade surpluses, whereas those that invest more than they save run deficits. These global deficits and surpluses are likely to influence levels of bilateral deficits and surpluses.

14. This definition follows that of Grubert and Mutti (1996).

15. One can also break down the sample to see if the tax effects remain the same for rich and poor countries. I broke down the sample into high-income countries (those with per capita incomes greater than $\$ 9,000$ ) and other countries. The coefficients on the effective tax variable were statistically indistinguishable from each other in the two regressions.

I also tried specifications that looked at an inverse tax rate (equal to $1 /(.1+$ ETR), follow- 
Table 7.3

Dependent Variable: Intrafirm Trade Balance

\begin{tabular}{lcc}
\hline Independent & ETR $<$ U.S. Rate & $\begin{array}{c}\text { ETR }>\text { U.S. Rate } \\
(2)\end{array}$ \\
\hline Variables & .8772 & -.0230 \\
Effective tax rate & $(.1770)$ & $(.2005)$ \\
Real exchange rate & .0028 & .0003 \\
& $(.0004)$ & $(.0005)$ \\
Income growth & -.0027 & -.0049 \\
& $(.0053)$ & $(.0076)$ \\
Share of sales in wholesale trade & .7163 & 1.657 \\
& $(.1849)$ & $(.2758)$ \\
Share of sales in manufacturing & -.2042 & .2920 \\
& $(.1148)$ & $(.1161)$ \\
Overall trade balance & .5776 & 1.107 \\
& $(.0762)$ & $(.1068)$ \\
Unaffiliated trade balance & .0472 & -.1030 \\
European country dummy & $(.0413)$ & $(.0532)$ \\
& .2689 & .0374 \\
Japan dummy & $(.0482)$ & $(.0689)$ \\
Constant & & .4213 \\
$N$ & & $(.1175)$ \\
Adjusted $R^{2}$ & -.4606 & -.0112 \\
& $(.1068)$ & $(.1596)$ \\
\end{tabular}

Note: Standard errors are in parentheses. The sample is divided into two subsets based on a comparison of the average effective tax rate (ETR) with the U.S. marginal tax rate. For variable definitions refer to table 7.1 note.

One advantage of considering these specifications in the context of a panel data set is that this allows a closer inspection of the influence of taxes on intrafirm trade both across countries and over time. It is also easier to consider how the relationships shown in the regressions of table 7.2 change due to particular events. One very important change that occurred during this time period was the Tax Reform Act of 1986 (TRA 1986). Many important changes in tax law affected MNCs at this time; perhaps the most important, TRA 1986 reduced the marginal corporate income tax rate from 46 to 34 percent. As Grubert, Randolph, and Rousslang (1996) point out, this was likely to increase the number of firms in excess credit position, giving firms a greater incentive to lower foreign taxes. These types of effects would indicate more income-shifting activity after 1986. However, Grubert, Randolph, and Rousslang note that the share of firms with excess credits did not increase post-1986. This could

ing Grubert and Mutti 1996) to test the hypothesis that there may be magnified sensitivity to low tax rates. In my specifications, however, I did not find that this variable improved the explanatory power of the regression, nor did it appear to be more statistically significant than the more conventional tax variable. 
have been due to income shifting itself, but was also likely due to the fact that average foreign tax rates were falling during this time period, suggesting that there would be decreased incentives for income shifting.

Table 7.4 breaks down the sample into two time periods before and after TRA 1986. Although the 95 percent confidence interval for the effective tax rate variable coefficient overlaps, the point estimate for this coefficient is much higher in the earlier subperiod. This result may be due to the lesser dispersion of effective tax rates across countries in the later subperiod. In particular, the variation of the effective tax rate variable is smaller during the later time period. The mean of this variable is closer to the U.S. marginal tax rate during the later period as well.

Finally, the greater number of observations available using a panel of data improves the degrees of freedom, enabling more precise estimates of the coefficients. One might question, however, whether the overall tax effects are still discernible in individual cross sections. Table 7.5 shows estimates of the coefficients on the effective tax rate variable for the individual cross sections between 1982 and 1994. Of the thirteen years of cross sections, twelve of the coefficients on the effective tax rate variable are positive. Although only one of the coefficients is statistically significant at

Table 7.4 Dependent Variable: Intrafirm Trade Balance

\begin{tabular}{lcc}
\hline Independent & 1986 and Before & After 1986 \\
Variables & $(1)$ & $(2)$ \\
\hline Effective tax rate & .6977 & .3031 \\
& $(.1652)$ & $(.1204)$ \\
Real exchange rate & .0016 & .0007 \\
& $(.0007)$ & $(.0004)$ \\
Income growth & .0080 & -.0144 \\
& $(.0074)$ & $(.0059)$ \\
Share of sales in wholesale trade & 1.872 & .9053 \\
& $(.0301)$ & $(.1823)$ \\
Share of sales in manufacturing & .5378 & -.0103 \\
& $(.1380)$ & $(.1055)$ \\
Overall trade balance & .7945 & .8601 \\
& $(.1122)$ & $(.0813)$ \\
Unaffiliated trade balance & .0260 & .0431 \\
& $(.0683)$ & $(.0404)$ \\
European country dummy & .1365 & .1395 \\
& $(.0661)$ & $(.0507)$ \\
Japan dummy & .2841 & .4662 \\
& $(.1714)$ & $(.1357)$ \\
Constant & -.7863 & -.0762 \\
$N$ & $(.1492)$ & $(.1141)$ \\
Adjusted $R^{2}$ & 157 & 292 \\
\end{tabular}

Note: Standard errors are in parentheses. For variable definitions refer to table 7.1 note. 
Tax Coefficient Estimates for Cross Sections, 1982-1994

\begin{tabular}{|c|c|c|}
\hline Year & Coefficient on ETR & Significance Level (\%) \\
\hline 1982 & $\begin{array}{c}.6213 \\
(.2897)\end{array}$ & 87 \\
\hline 1983 & $\begin{array}{c}.2059 \\
(.5754)\end{array}$ & 27 \\
\hline 1984 & $\begin{array}{l}.8270 \\
(.4903)\end{array}$ & 89 \\
\hline 1985 & $\begin{array}{l}.8558 \\
(.4407)\end{array}$ & 93 \\
\hline 1986 & $\begin{array}{l}.9180 \\
(.5760)\end{array}$ & 87 \\
\hline 1987 & $\begin{array}{l}.7900 \\
(.4082)\end{array}$ & 93 \\
\hline 1988 & $\begin{array}{l}1.118 \\
(.380)\end{array}$ & 99 \\
\hline 1989 & $\begin{array}{l}.3835 \\
(.2953)\end{array}$ & 79 \\
\hline 1990 & $\begin{array}{l}.5680 \\
(.3322)\end{array}$ & 90 \\
\hline 1991 & $\begin{array}{l}.2469 \\
(.5681)\end{array}$ & 33 \\
\hline 1992 & $\begin{array}{c}.4308 \\
(.3193)\end{array}$ & 81 \\
\hline 1993 & $\begin{array}{r}-.0324 \\
(.3305)\end{array}$ & 7 \\
\hline 1994 & $\begin{array}{c}.4276 \\
(.3984)\end{array}$ & 71 \\
\hline
\end{tabular}

Note: The dependent variable is intrafirm trade balance. Standard errors are in parentheses.

a 95 percent confidence level, ten are statistically positive with greater than 70 percent confidence. These ten coefficients are estimated between 0.38 and 1.1, implying tax effects of a similar magnitude to those found in the panel regression.

\subsection{Intrafirm Trade between Foreign Affiliates of U.S. Firms}

Analyzing intrafirm trade patterns between different foreign affiliates of U.S. firms may be more complicated due to the combined influence of two effects: the incentive to shift profits to low-tax countries, and the incentive to avoid subpart $\mathrm{F}$ income in low-tax countries. Because the available trade data do not distinguish between the type of trade that triggers subpart $\mathrm{F}$ income and other trade, the influence of tax-minimizing incentives on intrafirm trade between foreign affiliates may be more difficult to isolate.

I consider a specification that explains sales from affiliates in a given 
host country to other foreign affiliates as a function of tax rates and other variables that are likely to affect these trade flows.

Sales to Affiliates in Other Countries

$$
\begin{aligned}
= & \alpha+\beta_{1} \text { Effective Tax Rate }_{i t} \\
& +\beta_{2} \text { Real Exchange Rate }_{i t} \\
& +\beta_{3} \text { ShareWh }_{i t}+\beta_{4} \text { ShareM }_{i t}+\beta_{5} \text { Sales }_{i t} \\
& +\beta_{6} \text { Sales to Nonaffiliates in Other Countries } \\
i t & +e_{i t}
\end{aligned}
$$

The dependent variable is the sales of affiliates in country $i$ (during year $t$ ) to affiliates in other foreign countries. This variable is no longer a trade balance because we do not have data on purchases of affiliates of a given host country from other foreign affiliates. (See fig. 7.1 for an illustration.) In addition, the data used are sales data rather than trade flows. ${ }^{16}$ These data differ from trade data in several respects, the most important of which is that sales data include services as well as goods. ${ }^{17}$

In this regression, if income-shifting effects predominate, we would expect the coefficient $\beta_{1}$ to be negative, indicating that affiliates based in lowtax countries overprice their sales to affiliates in other countries in order to shift income to low-tax locations. If subpart $\mathrm{F}$ provisions are very important, on the other hand, one might expect sales to other foreign affiliates to be lower for affiliates based in low-tax countries because such affiliates would want to avoid generating subpart $\mathrm{F}$ income.

Many of the independent variables are defined as in the previous analysis. A few changes are noteworthy, however. First, it is no longer meaningful to include a variable measuring economic growth in country $i$ because we are trying to explain sales to foreign countries other than country $i .{ }^{18}$ Second, the control variables are defined to be analogous to the dependent variable. In particular, total sales by affiliates in country $i$ (minus sales to other foreign affiliates) are included to proxy for influences that increase overall sales by affiliates in a given country. Sales to nonaffiliates in other

16. Trade data are not available. Also, trade data are calculated on a shipped basis, which usually requires firms to use shipping department invoices rather than accounting data.

17. One can take a similar approach to the previous specifications too, of course, in which case one would be explaining sales from affiliates in country $i$ to U.S. parents as a function of the standard independent variables, in addition to total sales by affiliates in country $i$ and sales by affiliates in country $i$ to nonaffiliates in the United States. Results from such a specification are shown in appendix table 7A.1. A tax rate 1 percentage point higher is associated with 0.36 percentage points fewer sales to the parent. (The elasticity of parent sales with respect to $(1-$ ETR $)$ is 0.72 ; at the mean taxes/income ratio, this corresponds to an elasticity with respect to the ETR of -0.36 .)

18. Dummy variables continue to be appropriate. For example, affiliates in European countries may be particularly likely to sell to affiliates in other countries due to their close geographical proximity to other European countries. 
Table 7.6

Dependent Variable: Sales to Affiliates in Other Foreign Countries

\begin{tabular}{lccc}
\hline Independent Variables & $(1)$ & $(2)$ & $(3)$ \\
\hline $1-$ effective tax rate & 1.648 & .8934 & 1.870 \\
& $(.286)$ & $(.2987)$ & $(.316)$ \\
Real exchange rate & -.0432 & -.1374 & .0704 \\
& $(.1464)$ & $(.1574)$ & $(.1484)$ \\
$1-$ share of sales in wholesale trade & .1859 & -1.608 & .4159 \\
& $(.4268)$ & $.414)$ & $(.4675)$ \\
$1-$ share of sales in manufacturing & -1.507 & -2.185 & -1.353 \\
& $(.259)$ & $. .263)$ & $(.278)$ \\
Total sales & .4569 & .3617 & .4374 \\
& $(.0654)$ & $(.0667)$ & $(.0683)$ \\
Sales to nonaffiliates in other foreign & .4606 & .6403 & .4484 \\
countries & $(.0507)$ & $(.0480)$ & $(.0526)$ \\
European country dummy & 1.126 & & 1.192 \\
& $(.307)$ & & $(.130)$ \\
Japan dummy & 1.286 & & 1.423 \\
& $(.307)$ & $.306)$ \\
Year & .0207 & .0119 & .0247 \\
& $(.0126)$ & $(.0137)$ & $(.0130)$ \\
Constant & -2.288 & -2.288 & -3.268 \\
& $(1.419)$ & $(1.541)$ & $(1.463)$ \\
$N$ & 480 & 480 & 421 \\
Adjusted $R^{2}$ & .789 & .751 & .794 \\
\hline
\end{tabular}

Note: All variables are in natural logs with the exception of dummy variables and year. Standard errors are in parentheses. Columns (1) and (2) include all country/year pairs for which data are available. Column (3) excludes those countries defined as tax havens, where the effective tax rate is less than 10 percent. "Sales to affiliates in other foreign countries" are sales by affiliates in country $i$ to affiliates in other foreign countries. For other variable definitions refer to table 7.1 note.

foreign countries control for characteristics of host-country affiliates that may make them more likely to ship goods to other countries. Third, a specification in natural logs is considered. Because both the dependent variables and the control variables are no longer in percentage terms, such a specification makes the results easier to interpret.

Table 7.6 shows the results. In column (1), the coefficient on the effective tax variable suggests that a 1 percent increase in the effective tax rate in country $i$ is associated with a 0.82 percent reduction in sales to other foreign affiliates. ${ }^{19}$ Sales to other foreign affiliates are positively related to the share of total sales in manufacturing in country $i$, the total sales of affiliates in country $i$ (excluding sales to other foreign affiliates), and the sales by affiliates in country $i$ to nonaffiliates in other foreign countries. Affiliates

19. The coefficient in the table indicates an elasticity of other country affiliated sales with respect to $1-$ ETR of 1.65. At the mean ETR, this corresponds to an elasticity with respect to the ETR of -0.82 . 
based in Europe and Japan also sell more to other foreign affiliates. When these dummy variables are excluded in column (2), the point estimate of the coefficient on the effective tax rate is smaller and, as one might expect, the coefficient on the share of sales in wholesale trade becomes much more important and statistically significant. ${ }^{20}$ Column (3) excludes from the sample those countries with effective tax rates less than 10 percent that are defined to be tax havens. Excluding tax havens has little effect on the results, so the demonstrated tax sensitivity is unlikely to be primarily a result of operations in very low tax countries.

There are several ways to interpret the tax coefficient results. It is possible that these results indicate tax-induced income shifting. Affiliates based in low-tax countries overprice their sales to other foreign affiliates in order to shift income from high-tax sources to low-tax sources. Although subpart $\mathrm{F}$ encourages affiliates in low-tax countries to avoid the type of sales to other affiliates that generates subpart $\mathrm{F}$ income, this influence is not apparent in the results, perhaps due to the fact that many types of trade do not generate subpart $\mathrm{F}$ income.

It is also possible that the tax coefficient result does not indicate taxinduced income shifting, but rather reflects the fact that low-tax locations are more attractive places to invest, and hence generate more trading activity of all types. One might hope that including the total level of sales in such countries as an independent variable would capture some of this influence, but it may not be adequate.

Another approach to this question would be to consider as a dependent variable the share of total sales that destined for affiliates in other countries. Figure 7.2 shows how total sales are typically divided between different destinations in the sample. If affiliates are attempting to shift income to low-tax locations, one would expect that affiliates in low-tax countries would see higher shares of their total sales going toward affiliates in other countries, relative to affiliates based in high-tax locations. Although there is no incentive to alter prices on local sales or sales to nonaffiliates, affiliates in low-tax countries have an incentive to overprice affiliate sales, whereas affiliates in high-tax countries have an incentive to underprice affiliate sales. Table 7.7 shows the results of these specifications. The estimates from column (1) indicate that an effective tax rate 1 percentage point higher in country $i$ is associated with a 0.26 percentage point lower share of sales that are destined for affiliates in other foreign countries. Figure 7.3 shows a graphical representation of this negative relationship between the effective tax rate of the affiliate country and the share of total sales that is destined for affiliates in other countries.

20. Affiliates based in European countries have an average of 29 percent of their total sales in wholesale trade, and affiliates based in Japan have an average of 26 percent of their sales in wholesale trade. Affiliates based in other countries average only 14 percent of their total sales in wholesale trade. 


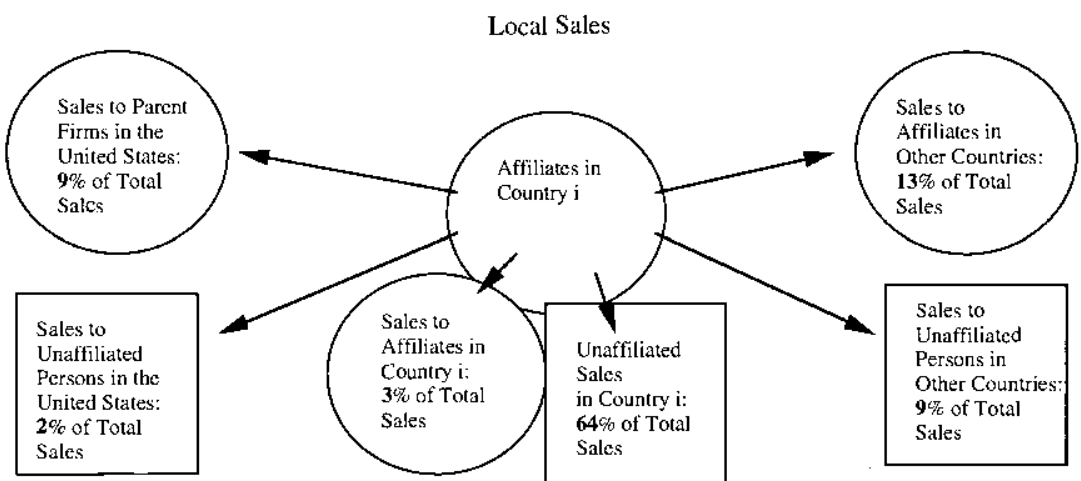

Fig. 7.2 The distribution of total sales to affiliates and nonaffiliates in the United States, locally, and in other countries

Table 7.7 Equations Estimating the Share of Total Sales That Are to Affiliates

\begin{tabular}{lccc}
\hline Independent Variables & $(1)$ & $(2)$ & $(3)$ \\
\hline Effective tax rate & -.2603 & .0093 & -.3181 \\
& $(.0182)$ & $(.0295)$ & $(.0331)$ \\
Real exchange rate & .0001 & .0000 & -.0005 \\
& $(.0001)$ & $(.0000)$ & $(.0001)$ \\
Income growth & .0023 & .0017 & .0024 \\
& $(.0009)$ & $(.0015)$ & $(.0017)$ \\
Share of sales in wholesale trade & -.1807 & -.2333 & -.3281 \\
& $(.0302)$ & $(.0501)$ & $(.0555)$ \\
Share of sales in manufacturing & .0663 & -.1547 & .0010 \\
European country dummy & $(.0163)$ & $(.0262)$ & $(.0297)$ \\
& .1380 & -.0716 & .0615 \\
Japan dummy & $(.0078)$ & $(.0130)$ & $(.0141)$ \\
& .0587 & -.0716 & -.0188 \\
Constant & $(.0212)$ & $(.0353)$ & $(.0383)$ \\
$N$ & .1355 & .2230 & .4062 \\
Adjusted $R^{2}$ & $(.0171)$ & $(.0283)$ & $(.0321)$ \\
& 477 & 484 & 467 \\
\end{tabular}

Note: Dependent variables are shares of total sales to affiliates in other foreign countries (column [1]), to affiliates (parents) in the United States (column [2]), and to affiliates both in the United States and in other foreign countries (column [3]). Standard errors are in parentheses. For other variable definitions see table 7.1 note.

One would expect a similar relationship between tax rates and the share of sales destined for parents in the United States. Column (2) considers this hypothesis. However, the coefficient on the effective tax rate is not estimated precisely, and is statistically indistinguishable from zero. Column (3) looks at the relationship between effective tax rates in country $i$ 


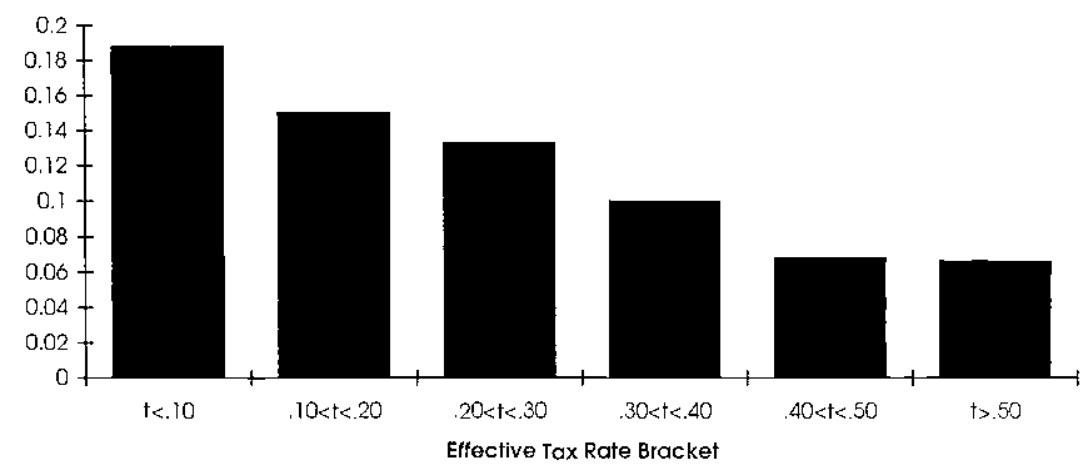

Fig. 7.3 The share of total sales destined for affiliates in other countries

and the combined share of sales to all other affiliates, both those in other foreign countries and parent firms in the United States. Here the coefficient on the effective tax rate implies that a 1 percentage point increase in the effective tax rate in country $i$ is associated with a 0.32 percentage point reduction in the share of sales to affiliates. ${ }^{21}$

These results provide evidence that the tax minimization strategies of MNCs may influence intrafirm trade. There is also a piece of indirect evidence regarding the effects of subpart F. Although concerns over triggering subpart $\mathrm{F}$ income do not appear to reduce sales from affiliates in low-tax countries to other affiliates, it is the case that affiliates operating in countries where a large share of sales are in wholesale trade have a lower share of sales to affiliates in other countries. Subpart F income is more likely when trade is in wholesale products, because subpart F income is generated only when trade between affiliates is in goods that are both manufactured outside the country of origin and sold for final use outside the country of origin. Thus, although subpart $\mathrm{F}$ may not substantially reduce most types of trade by affiliates in low-tax countries, it may reduce wholesale trade by such affiliates.

\subsection{Conclusions}

This paper studies the impact of tax-minimizing behavior on intrafirm trade patterns. Using data on the operations of U.S. parent companies and their foreign affiliates between 1982 and 1994, the paper examines the relationship between the effective tax rates faced by U.S. affiliates in different countries and intrafirm trade both between U.S. parents and their

21. Again, one can divide the sample into two subsets based on whether the ETR is lower or higher than the U.S. marginal tax rate. Results, shown in appendix tables 7A.2 and 7A.3 confirm the previous conclusion that the relationship between taxes and intrafirm trade is much stronger for low-tax countries. 
affiliates abroad and between different foreign affiliates of U.S. firms. The results indicate a clear relationship between taxes and intrafirm trade flows.

First, controlling for other factors that are likely to influence intrafirm trade balances, the data indicate that the United States has less favorable intrafirm trade balances with low-tax countries. This result fits with the theoretical expectation that firms minimizing their worldwide tax burdens will underprice U.S. exports to affiliates in low-tax countries and overprice U.S. imports from affiliates in low-tax countries. An effective tax rate in the affiliate country 10 percentage points lower is associated with an intrafirm trade balance relative to that country that is 4.4 percentage points smaller.

Second, additional evidence indicates that trade between U.S. affiliates in different foreign countries is also likely influenced by tax considerations. Sales by affiliates based in low-tax countries to affiliates in other countries are greater than one would otherwise expect. In addition, the share of affiliates' total sales that are destined for other affiliates is negatively related to the effective tax rate of the affiliate country. These results, along with the previous ones, provide evidence that tax-minimizing motivations may be influencing intrafirm trade patterns.

These results have several noteworthy implications. First, they indicate an important way in which intrafirm trade may be different from international trade conducted at arm's length. Intrafirm trade flows are influenced by the tax minimization strategies of MNCs. As Kant (1995) demonstrates, this tax-minimizing behavior can lead to situations in which intrafirm trade is perverse, such that intrafirm exports originate in the country with the higher marginal cost.

Second, the results add more evidence to the body of literature that has measured the magnitude of tax-induced transfer pricing. Much of the previous literature has found evidence of transfer price manipulation by focusing on the relationship between the taxes faced by affiliates located in different countries and firm profitabilities or U.S. tax liabilities. This paper adds evidence showing a clear relationship between the taxes faced by affiliates abroad and their intrafirm trade transactions. 


\section{Appendix}

Table 7A.1

Dependent Variable: Sales to U.S. Parents

\begin{tabular}{lc}
\hline Independent Variables & \\
\hline 1-effective tax rate & .7224 \\
& $(.2979)$ \\
1-share of sales in wholesale trade & 2.700 \\
& $(.495)$ \\
1-share of sales in manufacturing & -1.598 \\
& $(.273)$ \\
Total sales & 1.024 \\
& $(.0672)$ \\
Sales to nonaffiliates in the United States & .1607 \\
& $(.0425)$ \\
European country dummy & -.7818 \\
& $(.1515)$ \\
Japan dummy & -.1392 \\
& $(.3843)$ \\
Constant & -2.255 \\
& $(.450)$ \\
Adjusted $R^{2}$ & 508 \\
& .640 \\
\hline
\end{tabular}

Note: Standard errors are in parentheses. "Sales to U.S. parents" are sales by affiliates in country $i$ to U.S. parent companies. "Sales to nonaffiliates in the United States are sales by affiliates in country $i$ to nonaffiliated persons in the United States. Other variables are defined as in table 7.1. All variables are in natural logs with the exception of dummy variables.

Table 7A.2 Low Effective Tax Rate Sample

\begin{tabular}{lccc}
\hline Independent Variables & $(1)$ & $(2)$ & $(3)$ \\
\hline Effective tax rate & -.4607 & -.1693 & -.6300 \\
& $(.0405)$ & $(.0419)$ & $(.0600)$ \\
Real exchange rate & .0001 & -.0007 & -.0006 \\
& $(.0001)$ & $(.0001)$ & $(.0002)$ \\
Income growth & .0021 & .0011 & .0027 \\
& $(.0013)$ & $(.0013)$ & $(.0019)$ \\
Share of sales in wholesale trade & -.1933 & -.0452 & -.2388 \\
& $(.0418)$ & $(.0439)$ & $(.0625)$ \\
Share of sales in manufacturing & .1127 & .0212 & .1371 \\
& $(.0273)$ & $(.0284)$ & $(.0404)$ \\
European country dummy & .1540 & -.0990 & .0556 \\
& $(.0113)$ & $(.0117)$ & $(.0167)$ \\
Constant & .1594 & .2575 & .4169 \\
& $(.0237)$ & $(.0252)$ & $(.0362)$ \\
$N$ & 293 & 293 & 288 \\
Adjusted $R^{2}$ & .545 & .379 & .362 \\
\hline
\end{tabular}

Note: Dependent variables are shares of total sales to affiliates in other foreign countries (column [1]), to affiliates (parents) in the United States (column [2]), and to affiliates both in the United States and in other foreign countries (column [3]). Standard errors are in parentheses. Sample includes only those observations for which the effective tax rate is less than the U.S. marginal tax rate. For other variable definitions refer to table 7.1 note. 
Table 7A.3

High Effective Tax Rate Sample

\begin{tabular}{lccc}
\hline Independent Variables & $(1)$ & $(2)$ & $(3)$ \\
\hline Effective tax rate & -.0342 & .0743 & .0054 \\
& $(.0240)$ & $(.0780)$ & $(.0761)$ \\
Real exchange rate & .0001 & .0008 & -.0002 \\
& $(.0001)$ & $(.0002)$ & $(.0003)$ \\
Income growth & .0021 & -.0028 & -.0014 \\
& $(.0009)$ & $(.0030)$ & $(.0029)$ \\
Share of sales in wholesale trade & -.0901 & -.3678 & -.3951 \\
& $(.0329)$ & $(.1106)$ & $(.1066)$ \\
Share of sales in manufacturing & .0483 & -.2280 & -.0622 \\
& $(.0138)$ & $(.0447)$ & $(.0443)$ \\
European country dummy & .1046 & -.0436 & .0677 \\
& $(.0081)$ & $(.0278)$ & $(.0259)$ \\
Japan dummy & .0320 & -.0099 & -.0050 \\
& $(.0136)$ & $(.0453)$ & $(.0429)$ \\
Constant & .0247 & .1309 & .2448 \\
& $(.0188)$ & $(.0629)$ & $(.0613)$ \\
$N$ & 184 & 191 & 179 \\
Adjusted $R^{2}$ & .516 & .331 & .063 \\
\hline
\end{tabular}

Note: Dependent variables are shares of total sales to affiliates in other foreign countries (column [1]), to affiliates (parents) in the United States (column [2]), and to affiliates both in the United States and in other foreign countries (column [3]). Standard errors are in parentheses. Sample includes only those observations for which the effective tax rate is greater than the U.S. marginal tax rate. For other variable definitions refer to table 7.1 note.

\section{References}

Bernard, Jean-Thomas, and Weiner, Robert J. 1990. Multinational corporations, transfer prices, and taxes: Evidence from the U.S. petroleum industry. In Taxation in the global economy, ed. Assaf Razin and Joel Slemrod, 123-54. Chicago: University of Chicago Press.

Blomström, Magnus, Robert Lipsey, and Ksenia Kulchycky. 1988. U.S. and Swedish direct investment and exports. In Trade policy issues and empirical analysis, ed. Richard Baldwin, 259-97. Chicago: University of Chicago Press.

Bureau of Economic Analysis. 1982-1994. U.S. direct investment abroad: Annual and benchmark surveys. Washington, D.C.: U.S. Department of Commerce.

Clausing, Kimberly. 2000. Does multinational activity displace trade? Economic Inquiry 38 (2): 190-205.

Collins, Julie, Deen Kemsley, and Mark Lang. 1998. Cross-jurisdictional income shifting and earnings valuation. Journal of Accounting Research 36 (2): 209-30.

Deardorff, Alan V. 1998. Determinants of bilateral trade: Does gravity work in a neoclassical world? In The realization of the world economy, ed. Jeffrey A. Frankel, 3-31. Chicago: University of Chicago Press.

Diewert, W. Erwin. 1985. Transfer pricing and economic efficiency. In Multinationals and transfer pricing, ed. Lorraine Eden and Alan Rugman, 47-81. New York: St. Martin's Press.

Eden, Lorraine. 1985. The microeconomics of transfer pricing. In Multinationals and transfer pricing, ed. Lorraine Eden and Alan Rugman, 13-46. New York: St. Martin's Press. 
Grubert, Harry, William C. Randolph, and Donald J. Rousslang. 1996. Country and multinational company responses to the Tax Reform Act of 1986. National Tax Journal 49 (3): 341-58.

Grubert, Harry, and John Mutti. 1996. Do taxes influence where U.S. corporations invest? U.S. Department of the Treasury. Mimeograph.

- 1991. Taxes, tariffs and transfer pricing in multinational corporation decision making. Review of Economics and Statistics 17 (2): 285-93.

Harris, David, Randall Morck, Joel Slemrod, and Bernard Yeung. 1993. Income shifting in U.S. multinational corporations. In Studies in international taxation, ed. Alberto Giovannini, R. Glenn Hubbard, and Joel Slemrod, 277-302. Chicago: University of Chicago Press.

Hines, James R. 1997. Tax policy and the activities of multinational corporations. In Fiscal policy: Lessons from economic research, ed. Alan J. Auerbach, 401-45. Cambridge, Mass.: MIT Press.

Hines, James R., and Eric M. Rice. 1994. Fiscal paradise: Foreign tax havens and American business. Quarterly Journal of Economics 109 (1): 149-82.

Horst, Thomas. 1971. The theory of the multinational firm: Optimal behavior under different tariff and tax rates. Journal of Political Economy 79 (5): 1059-72.

International Monetary Fund. Various years. International financial statistics yearbook.

Jenkins, Glenn P., and Brian D. Wright. 1975. Taxation of income of multinational corporations: The case of the U.S. petroleum industry. Review of Economics and Statistics 57 (1): 1-11.

Kant, Chander. 1995. Minority ownership, deferral, perverse intrafirm trade and tariffs. International Economic Journal 9 (1): 19-37.

1990. Multinational firms and government revenue. Journal of Public Economics 42 (2): 135-47.

Kemsley, Deen. 1998. The effect of taxes on production location. Journal of Accounting Research 36 (2): 321-41.

Kopits, George F. 1976. Intra-firm royalties crossing frontiers and transfer pricing behavior. Economic Journal 86 (344): 791-805.

Lall, Sanjaya. 1973. Transfer pricing by multinational manufacturing firms. Oxford Bulletin of Economics and Statistics 35 (3): 173-95.

Lipsey, Robert E., and Merle Yahr Weiss. 1984. Foreign production and exports of individual firms. Review of Economics and Statistics 66 (2): 304-08.

. 1981. Foreign production and exports in manufacturing industries. Review of Economics and Statistics 63 (4): 488-94.

Rangan, Subramanian, and Robert Z. Lawrence. 1999. A prism on globalization: Corporate responses to the dollar. Washington: Brookings Institution Press.

Rapakko, Annamaria. 1990. Base company taxation. Boston: Deventer.

Zeile, William J. 1997. U.S. intrafirm trade in goods. Survey of Current Business 77 (2): $23-38$.

\section{Comment Deen Kemsley}

In this study, Clausing provides evidence that corporate tax incentives materially influence intrafirm trade balances. In particular, she finds a posi- 
tive relation between U.S. MNCs' intrafirm trade balances (i.e., dollardenominated exports less imports) and country-specific tax rates, which is consistent with the predicted effects of tax-induced transfer pricing. She also finds that patterns of sales among MNC affiliates in different foreign countries are consistent with tax-induced transfer pricing. Hence, Clausing extends the frontiers of empirical tax transfer pricing research to two new domains: trade balances and sales patterns among foreign affiliates.

This extension does not come without cost, for trade balances and sales patterns not only are functions of transfer pricing, but also are functions of international investment and production location decisions. As Clausing recognizes, it is difficult to distinguish between transfer pricing and investment location explanations for the empirical results, so she includes some controls for investment location. Nevertheless, future research is still required to distinguish between the two explanations, and to examine the relative magnitude of transfer pricing versus investment location effects.

My discussion of the paper proceeds as follows. I first analyze the relation between taxes and U.S.-foreign intrafirm trade balances. Next, I examine taxes and intrafirm trade among foreign affiliates of U.S. MNCs. Finally, I offer concluding remarks.

\section{Taxes and Intrafirm Trade between U.S. Parents and Affiliates}

United States MNCs have a tax incentive to shift taxable income away from high-tax foreign affiliates to the United States, and to shift taxable income from the United States to low-tax affiliates. Using a variety of different approaches, several prior studies have provided evidence that U.S. firms pursue both of these income-shifting strategies (e.g., Grubert and Mutti 1991, Harris, Morck, Slemrod, and Yeung 1993, and Collins, Kemsley, and Lang 1998). As long recognized, however, the U.S. foreign tax credit system mitigates this income-shifting incentive for firms without enough credits to offset the entire U.S. tax on foreign source income. For example, if a deficit-credit firm shifts taxable income from the United States to a low-tax country, the firm must recapture the taxable income in the United States upon repatriation of the shifted profits. As a result, shifting income across jurisdictions often provides only temporary tax savings - but even temporary savings provide some incentive for firms to shift profits. ${ }^{1}$

1. Clausing accounts for repatriation policies in her income-shifting model by letting $f$ represent the fraction of profits repatriated to the United States. Because repatriation triggers the U.S. tax on the income of low-tax affiliates, income-shifting incentives decrease in $f$ and go to 0 when $f$ equals 1 . In practice, firms' repatriation policies typically change over time, so $f$ is a complex function of several factors. For example, if firms eventually repatriate all foreign profits to the United States, and if the after-local-tax rates of return are the same in the foreign country as they are in the United States, then shifting income to the low-tax jurisdiction does not provide any net tax savings for a firm because the magnitude of the 
One way to shift income across tax jurisdictions is to manipulate transfer prices. For example, a U.S. MNC selling goods to a low-tax foreign affiliate can shift taxable income away from the United States by undercharging the low-tax affiliate for the goods. Undercharging the affiliate for the goods would reduce reportable exports to the affiliate, decreasing the intrafirm trade balance. On the other hand, the firm would have an incentive to reduce taxable income for high-tax affiliates by overcharging them for goods, which would increase reportable exports and intrafirm trade balances. All else being equal, therefore, tax-induced transfer pricing is expected to result in a positive relation between intrafirm trade balances and country-specific tax rates. Consistent with this expectation, Clausing reports a positive estimated coefficient for the effective tax rate variable in table 7.2.

In addition to transfer pricing incentives, MNCs have a tax incentive to locate production facilities and other investment in low-tax countries. Grubert and Mutti (1996) provide evidence that firms respond to this incentive. Placing production in low-tax countries instead of the United States could reduce reportable exports to the affiliates relative to imports from the affiliates, decreasing intrafirm trade balances with the low-tax countries. $^{2}$ Similarly, MNCs have an incentive to shift production from high-tax countries to the United States, and U.S. export tax incentive rules magnify this incentive. ${ }^{3}$ Kemsley (1998) provides evidence that firms respond to this tax incentive by exporting goods to high-tax countries, which would increase intrafirm trade balances. Like tax-induced transfer pricing, therefore, tax-induced investment location decisions generally are expected to result in a positive relation between intrafirm trade balances and country-specific tax rates.

A natural question, therefore, is whether the positive estimated coefficient for the effective tax rate (ETR) in table 7.2 captures transfer pricing effects, investment location effects, or both. ${ }^{4}$ Here, Clausing provides some support for the transfer pricing interpretation by controlling for the "overall" and "unaffiliated" U.S. trade balances with each foreign country. After

eventual U.S. repatriation tax grows at the discount rate (Scholes and Wolfson 1992). Within Clausing's model, these strict assumptions would imply that $f$ equals 1 for deficit-credit firms, even if the current rate of repatriation is less than 1 .

2. Placing production in low-tax countries could very well increase overall intrafirm activity with low-tax affiliates, both exports and imports. However, if the goods produced in lowtax countries are targeted for U.S. customers, imports from the low-tax affiliates typically would exceed exports to the affiliates.

3. Under IRC $\S 863$ (b), MNCs can treat half of their export profits as foreign source income. Hence export profits raise foreign tax credit limitations, allowing firms to use otherwise wasted excess foreign tax credits.

4. Unlike Grubert and Mutti (1996) and Kemsley (1998), Clausing uses each country's effective tax rate as an explanatory variable instead of using each country's marginal statutory tax rate. Both measures likely are subject to considerable measurement error, and it is not clear whether empirical results are sensitive to the choice of tax variable. 
including these controls, the ETR coefficient reflects a unique relation between tax rates and intrafirm trade balances, which is where we expect to find transfer pricing effects. However, tax-induced production location decisions also may have an especially strong influence on intrafirm trade balances, as firms choose to produce goods in low-tax countries and ship the goods to sales affiliates in high-tax countries. ${ }^{5}$ Hence it is unclear whether transfer pricing or investment location decisions drive the results presented in table 7.2.

Similarly, table 7.3 does not uniquely support transfer pricing effects, and it raises new questions. The evidence in this table indicates that the positive relation between ETRs and intrafirm trade balances is solely concentrated among countries with low tax rates. However, the tax incentive to shift taxable income away from high-tax countries to the United States increases in the foreign tax rate, and consistent with this incentive, Collins et al. (1998) provide evidence that firms shift a substantial amount of income to the United States. Indeed, the tax incentive to transfer price income from high-tax countries to the United States is less ambiguous than the incentive to shift income to low-tax countries, because firms must pay the difference between U.S. and low foreign tax rates upon repatriation of the shifted profits to the United States. ${ }^{6}$ From a transfer pricing perspective, therefore, it is unclear why the estimated tax effect exists only among low-tax countries.

Table 7.4 indicates that tax effects were greater before 1988 than after this date. Again, it is difficult to interpret this finding in terms of tax incentives. Firms with excess foreign tax credits derive permanent tax savings from transfer pricing income to lower-taxed jurisdictions, whereas firms with deficit foreign tax credits only defer taxes until repatriation. The percentage of firms with excess foreign tax credits increased substantially when the United States reduced corporate tax rates with the Tax Reform Act of 1986, so tax transfer pricing (and investment location) incentives are greater in the latter period, not weaker as suggested by table $7.4 .^{7} \mathrm{On}$

5. Using firm-level evidence, Kemsley (1998) finds that tax incentives induce U.S. MNCs to increase exports to unaffiliated foreign customers (given data constraints, I do not examine the influence of taxes on intrafirm exports). This finding suggests that the relation between taxes and production location is not unique to intrafirm settings, which provides some support for a transfer pricing interpretation of Clausing's results. However, Clausing's unaffiliated trade balance control variable captures only exports from unaffiliated U.S. firms to the affiliates of U.S. MNCs, so it is an imperfect (but potentially helpful) control for the taxinduced exports from U.S. MNCs to unaffiliated entities captured by Kemsley.

6. The finding by Collins, Hand, and Shackelford (chap. 6, this volume) that investors capitalize future repatriation taxes into share prices further limits the incentive to shift taxable income to low-tax countries.

7. As Clausing points out, variation in the ETR variable is relatively small during the latter time period, which could contribute to the weak results. Outliers also could contribute to the weak results after 1988, for, as reported in table 7.5, the estimated ETR coefficient is positive in all years except 1993, and the study does not provide any sensitivity tests to determine whether outliers account for the negative coefficient in this year. 
the other hand, many countries have implemented stronger tax rule restrictions against transfer price manipulation in recent years, which may contribute to the relatively weak results after 1988 .

\section{Taxes and Intrafirm Trade among Foreign Affiliates}

In a second set of tests, Clausing examines the hypothesis that sales among foreign affiliates are negatively related to the tax rates of the countries where the sales originate. That is, she examines whether low-tax foreign affiliates tend to sell more goods to high-tax affiliates than they buy from high-tax affiliates. Consistent with this hypothesis, she finds a negative relation (as reported in tables 7.6 and 7.7).

Again, it is difficult to distinguish between transfer pricing and investment location explanations for this result. On the one hand, transfer pricing income from high-tax affiliates to low-tax affiliates would increase (decrease) the reported sales of the low-tax (high-tax) affiliates. As Clausing notes, however, producing goods in low-tax countries and shipping the goods to high-tax affiliates also would result in high (low) reported sales for the low-tax (high-tax) affiliates. Therefore, she includes two control variables for the investment location explanation, sales to nonaffiliates in other countries and total sales. These variables may generally help control for tax-induced investment location decisions, but they are not specific enough to effectively rule out the possibility that firms are merely producing goods in low-tax countries for shipment to their high-tax affiliates.

\section{Conclusion}

In summary, therefore, Clausing provides rather convincing evidence that taxes influence the intrafirm trade patterns of U.S. MNCs, but the evidence does not clearly distinguish between transfer pricing and investment location explanations for this finding. I do not believe this ambiguity detracts from the paper's central message that taxes influence trade balances. Instead, the paper has the potential to stimulate a substantial amount of future research in this area.

Key unanswered questions for future consideration include the following. What are the relative magnitudes of the influences of tax-induced transfer pricing versus tax-induced investment location strategies on intrafirm trade balances? What are the relative magnitudes of tax-induced income shifting into versus out of the United States? What are the firmand industry-level determinants of firms' choices among various income shifting and investment location strategies? Have MNCs' preferred taxplanning strategies changed over time, and if so, why? I believe that answering these types of questions would provide us with a much more complete understanding of the links between taxes and multinational business practices than we can acquire by continuing to document different multinational tax strategies in isolation from each other. 


\section{References}

Collins, J., D. Kemsley, and M. Lang. 1998. Cross-jurisdictional income shifting and earnings valuation. Journal of Accounting Research, 36:209-30.

Grubert, H., and J. Mutti. 1996. Do taxes influence where U.S. corporations invest? Working Paper, 1996.

1991. Taxes, tariffs, and transfer pricing in multinational corporation decision making. Review of Economics and Statistics 17 (2): 285-93.

Harris, D., R. Morck, J. Slemrod, and B. Yeung. 1993. Income shifting in U.S. multinational corporations. In Studies in international taxation, ed. A. Giovannini, R. G. Hubbard, and J. Slemrod. Chicago: University of Chicago Press.

Kemsley, D. 1998. The effect of taxes on production location. Journal of Accounting Research, 36:321-42.

Scholes, M., and M. Wolfson. 1992. Taxes and business strategy: A planning approach. Englewood Cliffs, N.J.: Prentice Hall. 
